\title{
Reclassification of Roseobacter gallaeciensis Ruiz-Ponte et al. 1998 as Phaeobacter gallaeciensis gen. nov., comb. nov., description of Phaeobacter inhibens sp. nov., reclassification of Ruegeria algicola (Lafay et al. 1995) Uchino et al. 1999 as Marinovum algicola gen. nov., comb. nov., and emended descriptions of the genera Roseobacter, Ruegeria and Leisingera
}

Correspondence Thorsten Brinkhoff t.brinkhoff@icbm.de 


\section{INTRODUCTION}

The so-called Roseobacter clade (Giovannoni \& Rappé, 2000 ) within the Alphaproteobacteria includes cultivated and uncultivated organisms found in marine habitats all over the world. Characterization of isolates has demonstrated that the organisms in this group have very diverse metabolisms, including the production of secondary metabolites (Gram et al., 2002; Lafay et al., 1995). Some species of this cluster are even capable of producing antibiotic compounds (RuizPonte et al., 1999; Brinkhoff et al., 2004; Wagner-Döbler et al., 2004). Recently, it was demonstrated that an isolate from the German Wadden Sea, strain $\mathrm{T}^{\mathrm{T}}$, and Roseobacter gallaeciensis $\mathrm{BS} 107^{\mathrm{T}}$ were able to produce a new tropolone derivative, tropodithietic acid, which exhibits strong antibiotic properties against marine bacteria of various taxa and marine algae (Brinkhoff et al., 2004). Sequence similarity of the $16 \mathrm{~S}$ rRNA gene and physiological characteristics of strain $\mathrm{T}^{\mathrm{T}}$ revealed close affiliation with Rsb. gallaeciensis $\mathrm{BS} 107^{\mathrm{T}}$. On the basis of $16 \mathrm{~S}$ rRNA gene sequence, these two organisms showed highest similarity values to Leisingera methylohalidivorans and Ruegeria algicola. However, comparison of strain $\mathrm{T}^{\mathrm{T}}$ and Rsb. gallaeciensis $\mathrm{BS} 107^{\mathrm{T}}$ with Roseobacter denitrificans and Roseobacter litoralis showed striking differences in genetic similarity, pigmentation, presence of bacteriochlorophyll (Bchl) $a$ and production of antibiotics, as well as clear differences in chemical composition. In addition, the type species of the genera Roseobacter and Ruegeria did not group with these four organisms $\left(\mathrm{T}^{\mathrm{T}}{ }^{\mathrm{T}}, R s b\right.$. gallaeciensis $\mathrm{BS} 107^{\mathrm{T}}$, L. methylohalidivorans and Ruegeria algicola) based on 16S rRNA gene sequence comparisons and there were differences in their chemical composition and physiology. This led us to examine the way in which the genera Roseobacter and Ruegeria have been defined and to consider the consequences of our studies for the taxonomy of members of the Roseobacter clade in general. We have also examined the taxonomic significance of the production of Bchl $a$ in members of this group. The inclusion of species which do not produce Bchl $a$ in genera with species that do produce Bchl $a$ and carry out aerobic photosynthesis simply on the basis of a relatively high degree of $16 \mathrm{~S}$ rRNA gene sequence similarity has been criticized by Yurkov \& Beatty (1998) and Rathgeber et al. (2004), who suggest this overemphasizes the significance of $16 \mathrm{~S}$ rRNA gene sequence analysis.

On the basis of our results, we propose the reclassification of Rsb. gallaeciensis as the type species of a novel genus, Phaeobacter, and describe strain $\mathrm{T}^{\mathrm{T}}$ as the type strain of a novel species of this genus. In addition, it is necessary to reclassify Ruegeria algicola as the type species of a new genus as Marinovum algicola gen. nov., comb. nov., and to provide emended descriptions for the genera Roseobacter, Ruegeria and Leisingera.

\section{METHODS}

Source of bacteria. Strain $\mathrm{T}^{\mathrm{T}}$ was isolated from a $10^{\circ}$ dilution of a most-probable-number series using marine broth 2216 (MB 2216;
Difco) inoculated with surface water from a tidal mud flat $\left(53^{\circ} 42^{\prime}\right.$ $20^{\prime \prime} \mathrm{N} 07^{\circ} 43^{\prime} 11^{\prime \prime} \mathrm{E}$ ) of the German Wadden Sea (Brinkhoff et al., 2004). Rsb. gallaeciensis $\mathrm{BS} 107^{\mathrm{T}}$ was obtained from the Collection de l'Institut Pasteur, Paris, France. Rsb. denitrificans DSM $7001^{\mathrm{T}}$, Rsb. litoralis DSM $6996^{\mathrm{T}}$, Ruegeria algicola DSM $10251^{\mathrm{T}}$, Ruegeria atlantica DSM $5823^{\mathrm{T}}$ and L. methylohalidivorans DSM $14336^{\mathrm{T}}$ were obtained from the Deutsche Sammlung von Mikroorganismen und Zellkulturen (DSMZ), Braunschweig, Germany. All strains were cultured as recommended by the supplier.

Growth experiments. Strain $\mathrm{T}^{\mathrm{T}}$ was subcultured in MB 2216 or in artificial seawater (ASW) consisting of: $372 \mathrm{mM} \mathrm{NaCl}, 49 \cdot 1 \mathrm{mM}$ $\mathrm{MgCl}_{2}, 25.5 \mathrm{mM} \mathrm{Na}_{2} \mathrm{SO}_{4}, 9.3 \mathrm{mM} \mathrm{CaCl}, 8.5 \mathrm{mM} \mathrm{KCl}, 3.2 \mathrm{mM}$ $\mathrm{NaHCO}_{3}, 672 \mu \mathrm{M} \mathrm{KBr}, 360 \mu \mathrm{M} \mathrm{H}_{3} \mathrm{BO}_{4}, 213 \mu \mathrm{M} \mathrm{SrCl}_{2}, 57 \mu \mathrm{M} \mathrm{NaF}$, $32 \mu \mathrm{M} \mathrm{Na} \mathrm{SiO}_{3}, 20 \mu \mathrm{M}\left(\mathrm{NH}_{4}\right) \mathrm{NO}_{3}, 0 \cdot 4 \mathrm{mM}$ ferric citrate, $6 \mathrm{mM}$ $\mathrm{NH}_{4} \mathrm{Cl}$ and $0.263 \mathrm{mM} \mathrm{K}_{2} \mathrm{HPO}_{4}$. ASW medium was supplemented with different carbon sources as described below. Growth was determined by an increase in $\mathrm{OD}_{650}$ as measured with a spectrophotometer (DU 520; Beckman). Unless otherwise stated, assays were carried out using cells grown in MB 2216.

Temperature range for growth was determined between 4 and $45^{\circ} \mathrm{C}$ at intervals of $5{ }^{\circ} \mathrm{C}$, while the optimum was defined in $2^{\circ} \mathrm{C}$ increments between 25 and $35^{\circ} \mathrm{C}$. After plotting the growth curve for each temperature, the maximum growth rate $\left(\mu_{\max }\right)$ was calculated. The $\mathrm{pH}$ range $(4-10 \cdot 5)$ was tested in increments of $0 \cdot 5$, adjusted with sterile $\mathrm{NaOH}$ and $\mathrm{HCl}$ solutions (both $1 \mathrm{M}$ ). The optimum $\mathrm{pH}$ value was determined by growth experiments in a temperature- and $\mathrm{pH}$-controlled, 1.51 batch fermenter system (FairMenTec) with filter-sterilized medium. Oxygen concentration and $\mathrm{pH}$ value were monitored by oxygen and $\mathrm{pH}$ electrodes (Mettler Toledo), respectively. In determining optimum $\mathrm{pH}$, the $\mathrm{pH}$ was adjusted to $6 \cdot 0,7 \cdot 0,7 \cdot 5$, $8 \cdot 0$ and $8 \cdot 5$ by automatic titration with $\mathrm{NaOH}(1 \mathrm{M})$ or $\mathrm{H}_{2} \mathrm{SO}_{4}(1 \mathrm{M})$. Each experiment was incubated at $30{ }^{\circ} \mathrm{C}$. After plotting the growth curve, $\mu_{\max }$ was calculated for each $\mathrm{pH}$ value.

Experiments to determine optimum salinity were carried out in $250 \mathrm{ml}$ shake flasks at 180 r.p.m. and $25^{\circ} \mathrm{C}$ with a culture volume of $50 \mathrm{ml}$. Composition of the medium was $\left(1^{-1}\right): 5 \mathrm{~g}$ tryptone, $2 \cdot 5$ g yeast extract, $0.05 \mathrm{~g} \mathrm{~K}_{2} \mathrm{HPO}_{4}, 0.034 \mathrm{~g} \mathrm{SrCl}_{2}$ and $1 \mathrm{ml}$ trace element stock solution. The trace element stock solution consisted of $\left(1^{-1}\right): 80 \mathrm{~g} \mathrm{KBr}, 22 \mathrm{~g}$ $\mathrm{H}_{3} \mathrm{BO}_{3}, 4 \mathrm{~g} \mathrm{Na}_{2} \mathrm{SiO}_{3}, 2.4 \mathrm{~g} \mathrm{NaF}$ and $1.6 \mathrm{~g}\left(\mathrm{NH}_{4}\right) \mathrm{NO}_{3}$. For the determination of optimum salinity, a concentrated stock solution $\left(1^{-1}\right.$, $72 \mathrm{~g} \mathrm{NaCl}, 2 \cdot 1 \mathrm{~g} \mathrm{KCl}, 15 \cdot 5 \mathrm{~g} \mathrm{MgCl}_{2}, 3.4 \mathrm{~g} \mathrm{CaCl}_{2}, 12 \mathrm{~g} \mathrm{Na}_{2} \mathrm{SO}_{4}, 0.9 \mathrm{~g}$ $\mathrm{NaHCO}_{3}$ ) was used to prepare concentrations of $0,12 \cdot 5,25,37 \cdot 5,50$ and $65 \mathrm{~g}$ salts solution $\mathrm{l}^{-1}$. Since higher concentrations of some components in the mineral salt stock solution did not dissolve easily, the range of osmotolerance was studied with $\mathrm{NaCl}$ only. To determine the salinity range in which strain $\mathrm{T}^{\mathrm{T}}$ was able to grow, a concentrated $\mathrm{NaCl}$ solution was added to a minimal medium consisting of $26 \mathrm{mM}$ glucose, $6 \mathrm{mM} \mathrm{NH}_{4} \mathrm{Cl}, 2 \cdot 5 \mathrm{mM} \mathrm{MgCl}_{2}, 0 \cdot 263 \mathrm{mM} \mathrm{K}_{2} \mathrm{HPO}_{4}$ and $1 \mathrm{ml}$ trace element solution SL10 $1^{-1}$ (Tschech \& Pfennig, 1984) to final concentrations of $0 \cdot 01,0 \cdot 05,0 \cdot 1,0 \cdot 25,0 \cdot 37,0 \cdot 5,0 \cdot 7,1 \cdot 0,1 \cdot 5$ and $2 \cdot 0 \mathrm{M} \mathrm{NaCl}$. The requirement for $\mathrm{Na}^{+}$was studied in ASW supplemented with $26 \mathrm{mM}$ glucose where $\mathrm{Na}^{+}$was replaced with $\mathrm{K}^{+}$.

Cytochrome oxidase and catalase reaction assays were carried out according to the methods described by Smibert \& Krieg (1994). Exoenzyme activities (hydrolysis of gelatin, starch and Tween 80 ) were analysed with MB 2216 solidified with $4 \%(\mathrm{w} / \mathrm{v})$ gelatin or $1.5 \%(\mathrm{w} / \mathrm{v})$ agarose and supplemented with $0 \cdot 2 \%(\mathrm{w} / \mathrm{v})$ starch and $1 \%(\mathrm{v} / \mathrm{v})$ Tween 80, respectively, as described previously (Smibert \& Krieg, 1994). Reduction of nitrate was tested according to Smibert \& Krieg (1994) in ASW supplemented with $26 \mathrm{mM}$ glucose and a mixture of $20 \mathrm{mM}$ lactate and $5 \mathrm{mM}$ glucose. The experiments were analysed after 10 weeks incubation at $20^{\circ} \mathrm{C}$ in a $12 \mathrm{~h}$ daylight rhythm with $R s b$. denitrificans DSM $7001^{\mathrm{T}}$ used as a positive control. Production of $\mathrm{Bchl}$ 
$a$ was determined by spectrophotometric analysis. Cells grown at $25^{\circ} \mathrm{C}$ for $24 \mathrm{~h}$ in the dark or with a natural daylight rhythm were collected by centrifugation of $2 \mathrm{ml}$ culture broth (7000 r.p.m. for $5 \mathrm{~min}$ ) and resuspended in a drop of medium. Pigments were extracted in $1.5 \mathrm{ml}$ ice-cold acetone-methanol solution $(7: 2 \mathrm{v} / \mathrm{v})$ in the dark for $12 \mathrm{~h}$. Relative absorption was determined with a spectrophotometer (DU 520; Beckman) in the range 400-900 nm. Rsb. denitrificans DSM 7001 ${ }^{\mathrm{T}}$ was used as a positive control.

To determine the substrate spectrum of strain $\mathrm{T}^{\mathrm{T}}, 30$ different carbon sources were tested in test tubes. ASW was supplemented with the vitamins nicotinic acid, thiamine, pantothenate, pyridoxal hydrochloride, cyanocobalamin, riboflavin and biotin (all at $0.05 \mathrm{mg} \mathrm{l}^{-1}$ ). Growth experiments with ASW supplemented with $26 \mathrm{mM}$ glucose showed no growth limitation without the addition of vitamins, but slightly enhanced biomass production took place if all vitamins were supplied. The following carbon sources were added to the medium to a final concentration of $1 \mathrm{~g} \mathrm{l}^{-1}$ : (+)-D-xylose, (+)-D-glucose, $(+)$-D-mannose, $(+)$-D-galactose, $(-)$-D-fructose, $(+)$-L-arabinose, $(-)$-D-ribose, $(+)$-L-rhamnose, $(-)$-L-fucose, $(-)$-D-mannitol, $(-)$ D-sorbitol, (-)-D-glucosamine, sucrose, maltose, cellobiose, trehalose, lactose, sodium formate, sodium acetate, sodium pyruvate, sodium malate, sodium citrate, disodium succinate, sodium lactate, sodium propionate, starch, inulin, xylan, glycerol and Tween 80 . The polysaccharides starch, inulin and xylan were dissolved at $80{ }^{\circ} \mathrm{C}$; only xylan was not completely dissolved and the saturated solution was used. All media were adjusted to $\mathrm{pH} 7 \cdot 6$ and filter-sterilized (pore size $0 \cdot 2 \mu \mathrm{m}$; Sartorius). Three replicates of $7 \mathrm{ml}$ medium were inoculated with $15 \mu \mathrm{l}$ cells (washed twice with ASW) from an exponentially growing culture of strain $\mathrm{T}^{\mathrm{T}}$ incubated with MB 2216. Medium without any carbon source was used as a control. Growth was determined by measuring the $\mathrm{OD}_{650}$ after incubation at $20^{\circ} \mathrm{C}$ and shaking at 100 r.p.m. for 14 days. These experiments were repeated for L. methylohalidivorans DSM $14336^{\mathrm{T}}$ with 11 carbon sources as listed in Table 1 .

Utilization of L-alanine, L-arginine, L-asparagine, L-aspartic acid, L-cysteine, L-glutamine, L-glutamic acid, L-glycine, L-histidine, L-isoleucine, L-leucine, L-lysine, L-methionine, L-phenylalanine, Lproline, L-serine, L-threonine, L-tryptophan, L-tyrosine and L-valine (final concentration $1 \mathrm{mM}$ ) by strain $\mathrm{T}^{\mathrm{T}}$ was tested in $\mathrm{MB} 2216$ without organic carbon sources at $20^{\circ} \mathrm{C}$ for 1 week. Growth was inspected daily and determined by an increase in $\mathrm{OD}_{650}$.

To determine the differences in sole carbon usage between strain $\mathrm{T}^{\mathrm{T}}$, Rsb. gallaeciensis $\mathrm{BS} 107^{\mathrm{T}}$ and the methylotrophic L. methylohalidivorans DSM $14336^{\mathrm{T}}$, growth of these organisms on selected methylated substrates (all except butyrate) was tested in ASW, supplemented with the vitamin solution described above. Butyrate $(1 \mathrm{mM})$, betaine $(1 \mathrm{mM})$, methionine $(10 \mathrm{mM})$, dimethylsulphate (DMS, $0 \cdot 05 \mathrm{mM})$, methyl iodide $(0.13 \mathrm{mM})$ and methyl chloride $(0.37 \mathrm{mM})$ were added to the medium in test tubes or in sealed $50 \mathrm{ml}$ serum flasks with an airliquid ratio of $2: 1$ to reduce oxygen limitation. Comparison of growth of the organisms with MB 2216 in sealed flasks or cotton-stoppered Erlenmeyer flasks did not reveal growth limitations during 5 days incubation. Methyl iodide was added to sealed culture vessels as an aqueous solution and methyl chloride was added as a gas. Growth was inspected daily by measuring $\mathrm{OD}_{650}$ over a 1 week incubation period.

Antibiotic susceptibility of strain $\mathrm{T}^{\mathrm{T}}$ and Rsb. gallaeciensis $\mathrm{BS} 107^{\mathrm{T}}$ was tested as described previously (Brinkhoff et al., 2004).

Microscopic analyses. Colony morphology was studied with a Leitz Aristoplan microscope. Motility of strain $\mathrm{T} 5^{\mathrm{T}}$ was observed by light microscopy of an exponentially growing culture and the presence of flagella was examined using the staining procedures described by Ryu (1937). The number and type of flagella were examined by transmission electron microscopy (TEM), using cells from the early exponential phase grown in ASW and supplied with $15 \mathrm{mM}$ glucose. For TEM observations, cells were negatively stained with $1 \%(\mathrm{w} / \mathrm{v})$ phosphotungstic acid or studied unstained as described previously (Chavez et al., 2004) to preserve the native shape and, after air drying, copper grids (200 mesh; Plano) were examined by TEM (EM 902A; Zeiss).

Antimicrobial activity. Tests for antibiotic production and detection of antimicrobial activity of L. methylohalidivorans DSM $14336^{\mathrm{T}}$, $R s b$. litoralis DSM $6996^{\mathrm{T}}$ and Rsb. denitrificans DSM $7001^{\mathrm{T}}$ followed the method described by Brinkhoff et al. (2004).

Chemotaxonomic analyses. Respiratory lipoquinones and polar lipids were extracted from $100 \mathrm{mg}$ freeze-dried cells using the method described by Tindall (1990a, b). Respiratory lipoquinones were separated into their structural classes (menaquinones, ubiquinones etc.) by TLC. Bands were eluted and further separated and identified by HPLC, using an $\mathrm{RP}_{18}$ column (Tindall, 1996). Polar lipids were separated by two-dimensional chromatography and identified on the basis of their $R_{\mathrm{F}}$ values in combination with their reaction with specific staining reagents (Tindall, 1990a, b).

Analysis of fatty acid methyl esters. Fatty acid methyl esters were released from $20 \mathrm{mg}$ freeze-dried cells using methodologies which release only ester-linked fatty acids (M1) or ester- and amidelinked fatty acids (M2) (see Labrenz et al., 1998; Strömpl et al., 1999).

165 rRNA gene sequence analysis. PCR amplification and sequencing of the nearly complete $16 \mathrm{~S}$ rRNA gene of strain $\mathrm{T}^{\mathrm{T}}$ were performed according to methods described by Brinkhoff \& Muyzer (1997). Phylogenetic inferences were performed with the ARB software package [http://www.arb-home.de (Ludwig et al., 2004)]. Only sequences with more than $1300 \mathrm{bp}$ were considered in the calculations. A phylogenetic tree was constructed using neighbour-joining and maximum-likelihood analyses. Alignment positions at which fewer than $50 \%$ of sequences of the entire set of data had the same residues were excluded from the calculations to prevent uncertain alignments.

DNA base composition. The DNA $\mathrm{G}+\mathrm{C}$ content of cells of strain $\mathrm{T}^{\mathrm{T}}$ was determined by extracting genomic DNA according to Cashion et al. (1977) and subsequent determination of deoxyribonucleosides by HPLC (Mesbah et al., 1989; Tamaoka \& Komagata, 1984).

DNA-DNA hybridization. DNA-DNA hybridization analysis was performed using the renaturation method of De Ley et al. (1970) with the modifications of Huß et al. (1983) and Escara \& Hutton (1980). Renaturation rates were computed with the TRANSFER.BAS program (Jahnke, 1992).

\section{RESULTS AND DISCUSSION}

\section{Morphology}

Colonies of strain $\mathrm{T} 5^{\mathrm{T}}$ on agar are smooth and convex, with regular edges that become brownish with media containing ferric citrate (e.g. MB 2216) after $24 \mathrm{~h}$ incubation at $20^{\circ} \mathrm{C}$. Older colonies become dark brown. Single cells are ovoid rods, $1 \cdot 4-1 \cdot 9 \times 0 \cdot 6-0 \cdot 8 \mu \mathrm{m}$ (Fig. 1 ). Strain $\mathrm{T}^{\mathrm{T}}$ was shown to have a Gram-negative cell wall structure by cell lysis after the addition of $3 \%(\mathrm{w} / \mathrm{v}) \mathrm{KOH}$ (Gregersen, 1978). Spore formation was not observed. Cells are motile by means of a polar flagellum. 
Table 1. Major properties that differentiate Phaeobacter (Roseobacter) gallaeciensis $B S 107^{\top}$, Phaeobacter inhibens sp. nov. $\mathrm{T}^{\top}$ and Marinovum (Ruegeria) algicola DSM $10251^{\top}$ from each other and from related species

Species: 1, Marinovum (Ruegeria) algicola DSM $10251^{\mathrm{T}}$ (data from Lafay et al., 1995); 2, L. methylohalidivorans DSM $14336^{\mathrm{T}}$ (Schaefer et al., 2002); 3, Phaeobacter inhibens sp. nov. T5 ${ }^{\mathrm{T}}$; 4, Phaeobacter (Roseobacter) gallaeciensis BS107 ${ }^{\mathrm{T}}$ (Ruiz-Ponte et al., 1998); 5, Rsb. denitrificans DSM 7001 ${ }^{\mathrm{T}}$ (Shiba, 1991); 6, Rsb. litoralis DSM $6996^{\mathrm{T}}$ (Shiba, 1991). +, Positive result or growth; -, negative result or no growth; V, variable; ND, no data available.

\begin{tabular}{|c|c|c|c|c|c|c|}
\hline Characteristic & 1 & 2 & 3 & 4 & 5 & 6 \\
\hline Colony colour & Beige/pinkish & No pigment & Brown & Brown & Pink & Pink \\
\hline Bchl $a$ & - & $-\dagger$ & - & - & + & + \\
\hline DNA G $+\mathrm{C}$ content $(\mathrm{mol} \%)$ & $60^{\star}$ & $60 \cdot 5$ & $55 \cdot 7$ & $57 \cdot 6-58$ & $59 \cdot 6$ & $56 \cdot 3-58 \cdot 1$ \\
\hline $\begin{array}{l}\text { DNA-DNA hybridization with } \\
\text { P. gallaeciensis } \mathrm{BS} 107^{\mathrm{T}}(\%)\end{array}$ & $2-4^{*}$ & $<1$ & $16 \cdot 3-19 \cdot 6$ & 100 & $2^{*}$ & $3^{*}$ \\
\hline Growth at $4{ }^{\circ} \mathrm{C}$ & - & $+\dagger$ & + & - & + & + \\
\hline Growth at $37^{\circ} \mathrm{C}$ & + & $-\dagger$ & - & + & - & - \\
\hline Nitrate reduction & - & - & - & - & + (light) & - \\
\hline \multicolumn{7}{|l|}{ Enzyme activities: } \\
\hline Amylase & $(+)$ & + & - & - & - & - \\
\hline Tweenase 80 & - & $-\dagger$ & - & - & + & + \\
\hline Gelatinase & + & $-\dagger$ & - & - & + & + \\
\hline \multicolumn{7}{|l|}{ Substrate used: } \\
\hline Arabinose & $+\ddagger$ & $-\dagger$ & - & - & $+\ddagger$ & $\mathrm{V} \ddagger$ \\
\hline Rhamnose & $-1+\ddagger$ & $-\dagger$ & - & - & $+\ddagger$ & $+\ddagger$ \\
\hline Fucose & $-/+\ddagger$ & $-\dagger$ & - & ND & $+\ddagger$ & $+\ddagger$ \\
\hline Cellobiose & - & $-\dagger$ & + & + & $-\S$ & $-\ddagger$ \\
\hline Trehalose & + & $-\dagger$ & + & + & $-\S$ & $\mathrm{ND}$ \\
\hline Glucosamine & - & $-\dagger$ & + & - & $+\ddagger$ & $+\ddagger$ \\
\hline Acetate & - & - & + & + & + & + \\
\hline Citrate & + & - & + & - & + & + \\
\hline Succinate & - & $-\dagger$ & + & + & $+1-\ddagger$ & $+1-\ddagger$ \\
\hline Butyrate & - & $-\dagger$ & + & $+\dagger$ & - & - \\
\hline Tween 80 & - & $-\dagger$ & - & $-\dagger$ & $+\ddagger$ & $+\ddagger$ \\
\hline Glycerol & - & - & + & + & $-\ddagger$ & $-\ddagger$ \\
\hline Sorbitol & $-1+\ddagger$ & $-\dagger$ & + & + & $+\ddagger$ & $+\ddagger$ \\
\hline Serine & $\mathrm{ND}$ & - & + & - & ND & $\mathrm{ND}$ \\
\hline Leucine & $-\ddagger$ & $-\dagger$ & + & + & $-\ddagger$ & $-\ddagger$ \\
\hline Methyl iodide & $\mathrm{ND}$ & + & - & $-\dagger$ & $\mathrm{ND}$ & $\mathrm{ND}$ \\
\hline Methyl chloride & ND & + & - & $-\dagger$ & ND & $\mathrm{ND}$ \\
\hline DMS & ND & + & - & $-\dagger$ & $\mathrm{ND}$ & $\mathrm{ND}$ \\
\hline Betaine & ND & + & + & - & ND & ND \\
\hline \multicolumn{7}{|l|}{ Vitamin requirement: } \\
\hline Thiamine & + & - & - & + & + & + \\
\hline Nicotinic acid & - & - & - & - & + & + \\
\hline Biotin & + & - & - & - & + & + \\
\hline
\end{tabular}

*Data from Ruiz-Ponte et al. (1998).

$\dagger$ Data from this study.

$\ddagger$ Data from Labrenz et al. (1999).

$\$$ Data from Lafay et al. (1995)

\section{Physiological characteristics}

The results of physiological tests demonstrated that strain $\mathrm{T}^{\mathrm{T}}$ is a marine, strictly aerobic and $\mathrm{Na}^{+}$-requiring bacterium, with growth occurring between 0.01 and $<1.5 \mathrm{M}$ $\mathrm{NaCl}$ and optimally between 0.51 and $0.68 \mathrm{M} \mathrm{NaCl}$. Strain $\mathrm{T}^{\mathrm{T}}$ is capable of growth in a $\mathrm{pH}$ range of $6 \cdot 0-9 \cdot 5$, with an optimum of $\mathrm{pH} 7 \cdot 5$. Calculated growth rates were maximal between 27 and $29^{\circ} \mathrm{C}$, with $\mu_{\max }=0.43$ under optimum conditions during growth in a fermenter. Above $36^{\circ} \mathrm{C}$, no growth was observed.

The following carbon sources supported cell growth of strain $\mathrm{T}^{\mathrm{T}}$ : ( + )-D-xylose, ( + )-D-glucose, ( + )-D-mannose, 

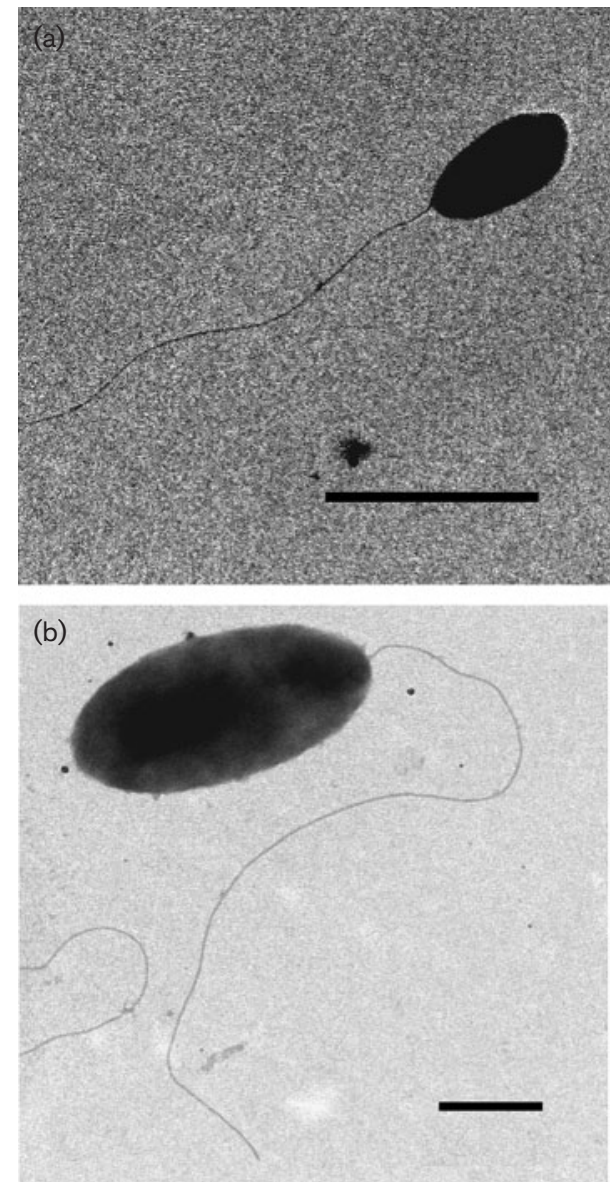

Fig. 1. Transmission electron micrographs of cells of Phaeobacter inhibens sp. nov. $\mathrm{T}^{\top}$. Unstained (a) and negatively stained cells (b) showing the typical rod-shaped cell morphology with a single polar flagellum. Bars, $2 \mu \mathrm{m}$ (a) and $0.5 \mu \mathrm{m}$ (b).

$(+)$-D-galactose, (-)-D-fructose, (-)-D-ribose, (-)-Dmannitol, (-)-D-sorbitol, (-)-D-glucosamine, sucrose, maltose, cellobiose, trehalose, sodium acetate, sodium pyruvate, sodium malate, sodium citrate, disodium succinate, sodium lactate, sodium propionate, sodium butyrate, xylan and glycerol. In addition, strain $\mathrm{T}^{\mathrm{T}}$ showed growth with all amino acids tested (see Methods). Further carbon sources that were tested, but not utilized, are listed in Methods.

Growth experiments with $(+)$-L-arabinose, $(+)$-L-rhamnose, (-)-L-fucose, (-)-D-sorbitol, D-glucosamine, cellobiose, trehalose, sodium butyrate, disodium succinate, Tween 80, leucine, DMS, methyl iodide, methyl chloride and betaine confirmed earlier results for L. methylohalidivorans, indicating that this organism appears to be an obligate methylotroph, capable of growth on only a limited number of substrates (Schaefer et al., 2002). L. methylohalidivorans DSM $14336^{\mathrm{T}}$ utilized all methylated substrates tested (betaine, methionine, DMS, methyl iodide and methyl chloride); however, strain $\mathrm{T}^{\mathrm{T}}$ and Rsb. gallaeciensis
$\mathrm{BS} 107^{\mathrm{T}}$ were not able to grow with DMS, methyl iodide or methyl chloride. In contrast to strain $\mathrm{T}^{\mathrm{T}}$, Rsb. gallaeciensis $\mathrm{BS} 107^{\mathrm{T}}$ did not grow with betaine.

Strain $\mathrm{T}^{\mathrm{T}}$ and Rsb. gallaeciensis $\mathrm{BS} 107^{\mathrm{T}}$ are capable of producing the antibiotic tropodithietic acid, which inhibits growth of bacteria belonging to a number of different taxa and marine algae (Brinkhoff et al., 2004). In the case of strain $\mathrm{T}^{\mathrm{T}}$, it was shown that the antibiotic is produced during the exponential growth phase (Brinkhoff et al., 2004). No inhibitory effects could be observed with Ruegeria algicola, Ruegeria gelatinovorans, L. methylohalidivorans, Rsb. litoralis or Rsb. denitrificans (Brinkhoff et al., 2004; this study). Cells of strain $\mathrm{T}^{\mathrm{T}}$ and Rsb. gallaeciensis $\mathrm{BS} 107^{\mathrm{T}}$ are susceptible to penicillin G, streptomycin sulphate and chloramphenicol. The results of the phenotypic characterization are summarized in Table 1.

\section{Genetic analyses}

Analysis of the 16S rRNA gene sequences of Rsb. gallaeciensis, Rsb. denitrificans and Rsb. litoralis indicated that $R s b$. gallaeciensis does not group with the other Roseobacter species, but instead groups with L. methylohalidivorans and $R$. algicola as its closest described relatives, regardless of which method of analysis is used (Fig. 2). Other features also differentiate $R s b$. gallaeciensis from $R s b$. denitrificans and Rsb. litoralis. Members of the genus Roseobacter were originally defined as pink-pigmented, aerobic phototrophic bacteria containing Bchl a (Shiba, 1991). However, Rsb. gallaeciensis is brown-pigmented, not phototrophic and does not contain Bchl $a$. A former member of the genus Roseobacter, Roseobacter algicola ATCC $51440^{\mathrm{T}}$ (Lafay et al., 1995), isolated from a culture of the toxin-producing dinoflagellate Prorocentrum lima, does not produce Bchl $a$ and has since been reclassified as Ruegeria algicola (Uchino et al., 1998). Rsb. gallaeciensis was placed in the genus Roseobacter on the basis that the 16S rRNA gene sequence of the type strain, $\mathrm{BS} 107^{\mathrm{T}}$, clustered closest to R. algicola at a time when the numbers of described species and available sequences of the Roseobacter clade were significantly lower than at present. These findings, as well as the additional physiological differences listed in Table 1, are indicative of the need for the reclassification of Rsb. gallaeciensis in a novel genus.

The DNA G + C content of strain $\mathrm{T}^{\mathrm{T}}$ was determined to be $55 \cdot 7 \mathrm{~mol} \%$. This value is similar to that of Rsb. gallaeciensis $\mathrm{BS} 107^{\mathrm{T}}(57 \cdot 6-58 \mathrm{~mol} \%)$ and Rsb. litoralis $(56 \cdot 3-58 \cdot 1 \mathrm{~mol} \%)$, but differs from the DNA G + C content of L. methylohalidivorans $(60.5 \mathrm{~mol} \%)$ and Rsb. denitrificans (59.6 mol\%). Since a $10 \mathrm{~mol} \%$ difference in DNA G + C content has been proposed as a clear differentiating criterion for species at the genus level (Stackebrandt \& Liesack, 1993), these results demonstrate no significant distinctive features. However, it is evident that organisms which have diverged fairly recently on an evolutionary time scale will share many genes and, within these genes, codon usage will also be similar, both of these effects being reflected in the overall DNA $G+C$ content. The effect of DNA G $+\mathrm{C}$ content on codon usage 


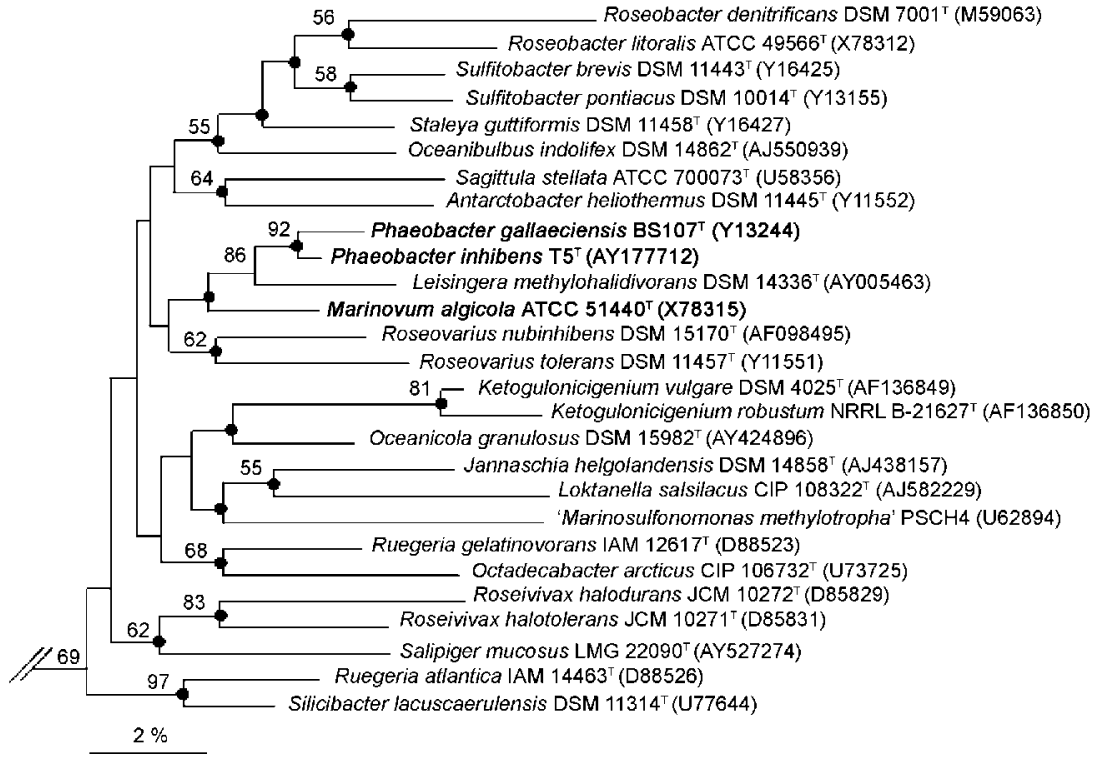

Fig. 2. Neighbour-joining tree showing the phylogenetic relationships of Phaeobacter

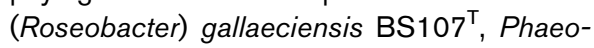
bacter inhibens sp. nov. $\mathrm{T}^{\top}$, Marinovum (Ruegeria) algicola ATCC $51440^{\top}$ and representatives of the Rhodobacteraceae within the Alphaproteobacteria based on $16 \mathrm{~S}$ rRNA gene sequence similarity. Only bootstrap values $>50 \%$ (derived from 2000 replicates) are shown. Filled circles indicate nodes also recovered reproducibly with maximum-likelihood. Selected members of the Gammaproteobacteria were used as an outgroup (not shown) to define the root of the tree. GenBank sequence accession numbers are given in parentheses. Bar, 0.02 substitutions per nucleotide position. and its significance in an evolutionary framework has been outlined by De Ley (1967).

DNA-DNA hybridization studies revealed low levels of DNA-DNA relatedness, all below $5 \%$, between Rsb. gallaeciensis $\mathrm{BS} 107^{\mathrm{T}}$ and Rsb. denitrificans DSM $7001^{\mathrm{T}}$, Rsb. litoralis DSM $6996^{\mathrm{T}}$, L. methylohalidivorans DSM $14336^{\mathrm{T}}$ and Ruegeria algicola DSM $10251^{\mathrm{T}}$ (Table 1). The hybridization results, differences in pigmentation, antibiotic production, exoenzyme activities and utilization of a great variety of substrates, though not of methyl compounds, indicate that Rsb. gallaeciensis $\mathrm{BS} 107^{\mathrm{T}}$ does not belong to the genus Leisingera, despite a 16S rRNA gene sequence similarity of $97 \cdot 6 \%$ to L. methylohalidivorans DSM $14336^{\mathrm{T}}$, or to the genus Roseobacter. The 16S rRNA gene sequences of Rsb. gallaeciensis $\mathrm{BS} 107^{\mathrm{T}}$ and strain $\mathrm{T}^{\mathrm{T}}$ differ only at 13 positions ( $99 \%$ similarity). DNA-DNA hybridization analysis, however, revealed a DNA-DNA relatedness of 16.3-19.6\% between Rsb. gallaeciensis $\mathrm{BS} 107^{\mathrm{T}}$ and strain $\mathrm{T}^{\mathrm{T}}$. According to Wayne et al. (1987), the definition of members of the same species generally includes DNA-DNA hybridization values of more than $70 \%$. Thus, we conclude that $R s b$. gallaeciensis $\mathrm{BS} 107^{\mathrm{T}}$ represents a member of a novel genus, for which further support was sought via analysis of the chemical composition of the cell.

The chemical composition of all strains examined confirmed that ubiquinones were the sole respiratory lipoquinones present and that Q10 predominated. The predominance of Q10 is a feature characteristic of many, but not all, members of the Alphaproteobacteria. All members of the Roseobacter clade examined to date also have Q10 as the dominant respiratory lipoquinone. The polar lipids of all strains examined in this study consisted mainly of phospholipids, although amino lipids were present in some of the strains (Fig. 3). The polar lipid compositions of Rsb. denitrificans DSM $7001^{\mathrm{T}}$ and Rsb. litoralis DSM $6996^{\mathrm{T}}$ were very similar, as were the polar lipid compositions of strain $\mathrm{T}^{\mathrm{T}}$ and Rsb. gallaeciensis $\mathrm{BS} 107^{\mathrm{T}}$. However, there were clear differences between the two groups. The polar lipids of Ruegeria algicola DSM $10251^{\mathrm{T}}$, Ruegeria atlantica DSM $5823^{\mathrm{T}}$ and L. methylohalidivorans DSM $14336^{\mathrm{T}}$ were not identical to each other or to any of the other strains examined (Fig. 3). The fatty acid composition of all strains was dominated by $18: 1 \omega 7 c$, but this is also a feature of the vast majority of species within the Alphaproteobacteria. Despite being listed in many recent publications as being a diagnostic characteristic, the presence of this fatty acid in major amounts is neither species- nor genus-specific. The major differences/similarities between the strains were found in the fatty acids that were present in lower concentrations. In particular, distinct differences between strains were found in the distribution of the hydroxy fatty acids and the nature of their linkage (ester- and/or amide-linked). It should be noted that, although 3-oxo-14:0 has been reported to be present in members of the genus Roseobacter (Neumann et al., 1995), the compound identified as 3-OH $14: 1 / 3$-oxo 14:0 did not co-elute with authentic 3-oxo-14:0, although mass spectrometry indicated that the compound had a molecular mass suggesting that it was a derivative of a $3-\mathrm{OH}$ $14: 0$ containing one double bond. In the absence of more detailed studies, this compound is listed as $3-\mathrm{OH} 14: 1 / 3$ oxo 14:0 in Table 2. Rsb. denitrificans and Rsb. litoralis were indistinguishable on a qualitative basis, as were strains $\mathrm{T}^{\mathrm{T}}$ and Rsb. gallaeciensis. Taken together, the chemical data are indicative of the fact that Rsb. denitrificans and Rsb. litoralis may be grouped together to the exclusion of other species currently assigned to the genus Roseobacter. Strain $\mathrm{T}^{\mathrm{T}}$ and $R s b$. gallaeciensis $\mathrm{BS}_{107^{\mathrm{T}}}$ also formed a distinct group. The chemical evidence also provides support for the exclusion of Ruegeria algicola from the genus Ruegeria. The value of chemical data in both a taxonomic and evolutionary context has been a topic in the literature for almost the last half 

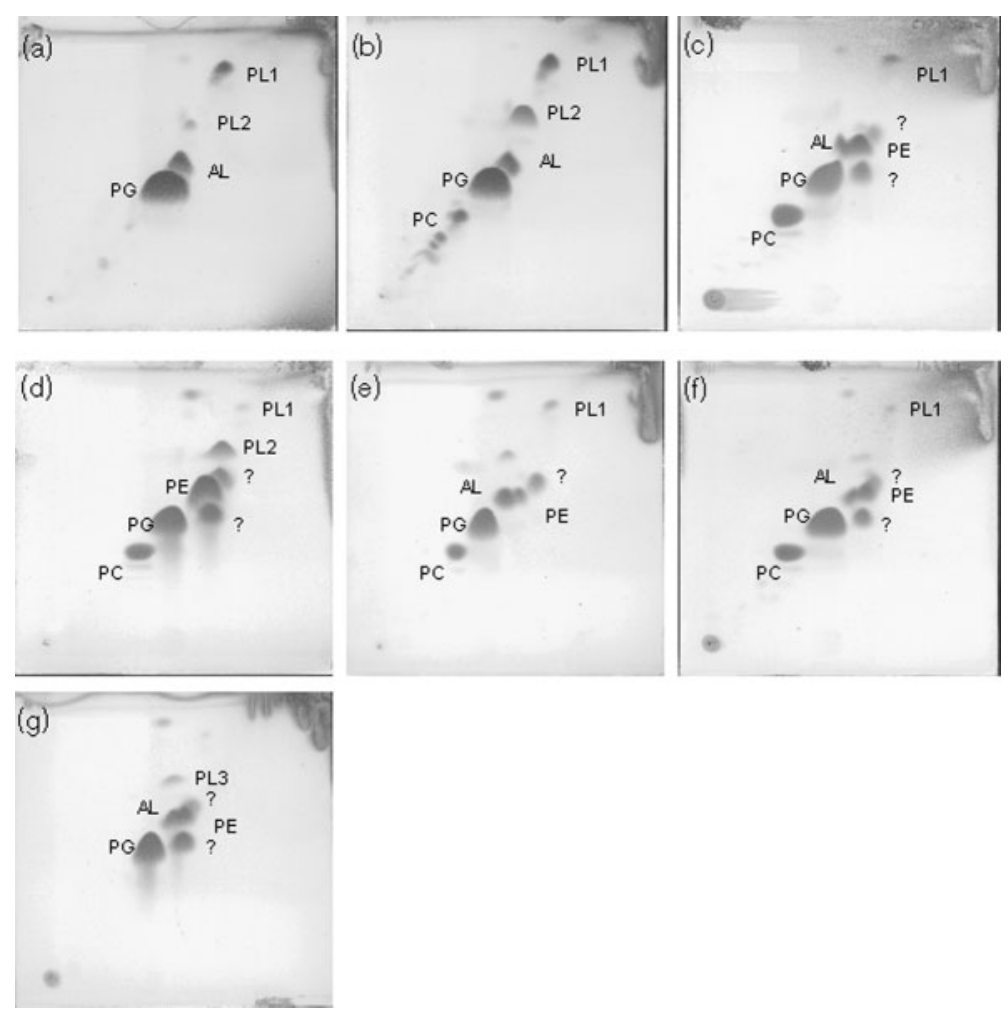

Fig. 3. TLC chromatograms of the polar lipids of Phaeobacter (Roseobacter) gallaeciensis comb. nov. and related strains. (a) Rsb. litoralis DSM 6996' ; (b) Rsb. denitrificans DSM $7001^{\top}$; (c) Phaeobacter (Roseobacter) gallaeciensis $\mathrm{BS}_{107}^{\mathrm{T}}$; (d) Ruegeria atlantica DSM $5823^{\mathrm{T}}$; (e) Ruegeria algicola DSM $10251^{\mathrm{T}}$; (f) Phaeobacter inhibens DSM $16374^{\mathrm{T}}$; (g) L. methylohalidivorans DSM $14336^{\top}$. Chromatograms were run as described in Methods, the first dimension (horizontal, from left to right) in chloroform/ methanol/water (65:25:4, by vol.) and the second dimension (vertically, from top to bottom) in chloroform/methanol/acetic acid/ water (80:12:15:4, by vol.). Total lipids were visualized using $5 \%$ ethanolic molybdophosphoric acid (heated for $30 \mathrm{~min}$ at $\left.150^{\circ} \mathrm{C}\right)$. Specific stain reagents were used, as described in Methods, for the detection of functional groups. PG, Phosphatidylglycerol; PE, phosphatidylethanolamine; PC, phosphatidylcholine; PL1, PL2, PL3, unidentified phospholipids; AL, aminolipid; ?, lipids which did not react in a specific fashion with the spray reagents and remain to be characterized.

Table 2. Fatty acid content (\%) of the strains used in this study

Strains: 1, Marinovum (Ruegeria) algicola DSM $10251^{\mathrm{T}}$; 2, L. methylohalidivorans DSM 14336 ${ }^{\mathrm{T}}$; 3, Phaeobacter (Roseobacter) gallaeciensis CIP $105210^{\mathrm{T}} ; 4$, Phaeobacter inhibens sp. nov. DSM $16374^{\mathrm{T}} ; 5$, Ruegeria atlantica DSM 5823 ${ }^{\mathrm{T}} ; 6$, Rsb. litoralis DSM 6996 ${ }^{\mathrm{T}} ; 7$, Rsb. denitrificans DSM $7001^{\mathrm{T}}$. M1 and M2 refers to the method of differential hydrolysis (see Methods) which distinguishes between ester- and amide-linked fatty acids. Fatty acids labelled ? were not unambiguously identified. tr, Trace.

\begin{tabular}{|c|c|c|c|c|c|c|c|c|c|c|c|c|c|c|}
\hline Fatty acid & \multicolumn{2}{|c|}{1} & \multicolumn{2}{|c|}{2} & \multicolumn{2}{|c|}{3} & \multicolumn{2}{|c|}{4} & \multicolumn{2}{|c|}{5} & \multicolumn{2}{|c|}{6} & \multicolumn{2}{|c|}{7} \\
\hline $14: 1$ & & & $3 \cdot 18$ & $2 \cdot 27$ & $3 \cdot 14$ & $2 \cdot 14$ & $2 \cdot 80$ & $2 \cdot 19$ & & & & & & \\
\hline $14: 0$ & & & & & & & & & $3 \cdot 95$ & $3 \cdot 84$ & & & & \\
\hline $3-\mathrm{OH} \mathrm{12:0}$ & $1 \cdot 13$ & $1 \cdot 64$ & & $2 \cdot 27$ & & $1 \cdot 27$ & & $1 \cdot 59$ & $5 \cdot 52$ & $8 \cdot 67$ & & & & \\
\hline $16: 1 \omega 7 c$ & $\operatorname{tr}$ & $\operatorname{tr}$ & $\operatorname{tr}$ & $\operatorname{tr}$ & $\operatorname{tr}$ & $\operatorname{tr}$ & $\operatorname{tr}$ & $\operatorname{tr}$ & $\operatorname{tr}$ & $\operatorname{tr}$ & & $0 \cdot 36$ & & $0 \cdot 53$ \\
\hline $16: 0$ & & & $5 \cdot 16$ & $5 \cdot 08$ & $3 \cdot 96$ & $3 \cdot 79$ & $4 \cdot 02$ & $3 \cdot 83$ & $5 \cdot 94$ & $6 \cdot 25$ & $1 \cdot 51$ & $1 \cdot 11$ & $1 \cdot 58$ & $1 \cdot 56$ \\
\hline$?$ & & & & & & & & & & & & $0 \cdot 35$ & $0 \cdot 86$ & $0 \cdot 76$ \\
\hline$?$ & & & & & & & & & & & $1 \cdot 81$ & $1 \cdot 50$ & & \\
\hline 2-OH 16:0 & & & $8 \cdot 92$ & $6 \cdot 97$ & $5 \cdot 05$ & $3 \cdot 90$ & $4 \cdot 47$ & $3 \cdot 10$ & $10 \cdot 08$ & $10 \cdot 44$ & & & & \\
\hline $18: 0$ & $2 \cdot 48$ & $2 \cdot 73$ & $0 \cdot 95$ & $0 \cdot 97$ & $2 \cdot 60$ & $2 \cdot 57$ & $2 \cdot 66$ & $3 \cdot 14$ & $2 \cdot 35$ & $2 \cdot 28$ & $1 \cdot 59$ & $1 \cdot 39$ & $2 \cdot 71$ & $2 \cdot 75$ \\
\hline 11-methyl $18: 1 \omega 7 c$ & $3 \cdot 34$ & $3 \cdot 17$ & $6 \cdot 07$ & $6 \cdot 86$ & $6 \cdot 06$ & $6 \cdot 60$ & $6 \cdot 52$ & $7 \cdot 45$ & $30 \cdot 93$ & $30 \cdot 40$ & & $0 \cdot 54$ & & \\
\hline$?$ & & & & & & & & $0 \cdot 98$ & & & & & & \\
\hline$?$ & & $2 \cdot 58$ & & 0.95 & & 0.57 & & $0 \cdot 61$ & & $2 \cdot 30$ & & $1 \cdot 41$ & & $1 \cdot 28$ \\
\hline
\end{tabular}

${ }^{*}$ This fatty acid was not unambiguously identified and is not identified in the MIDI system. 
century and this work supports the point of view clearly expressed by Tindall (1994).

In examining the current data, it is appropriate to look also at the way that genera within the Roseobacter clade have been defined in the past so that one may be able to avoid continual nomenclatural and taxonomic rearrangements in the future. When originally described, the genus Roseobacter consisted of only two species. A third species was added, Rsb. algicola, on the basis that it was 'phylogenetically close' and that it also formed a monophyletic group with the other two species. Phenotypic differences were largely ignored in favour of a 'phylogenetic' (i.e. 16S rRNA gene sequence) approach. In conducting further arrangements within the Roseobacter clade, Uchino et al. (1998) also favoured this approach, reclassifying Rsb. algicola as Ruegeria algicola and transferring some marine 'agrobacteria' to the genus Ruegeria (Ruegeria atlantica and Ruegeria gelatinovora) based on the fact that they also formed a monophyletic group, despite the clear heterogeneity in the chemical data they presented. Work by Tindall and co-workers (Labrenz et al., 1998, 1999, 2000, 2005; Wagner-Döbler et al., 2004; Biebl et al., 2005a, b) on members of the Roseobacter clade has followed the approach outlined here, based on a general principle that evolutionary groups are reflected in the chemical composition of the cell (Tindall, 1994) and also at other levels. This approach has indicated that using $16 \mathrm{~S}$ rRNA gene sequence data alone for defining taxa has a number of disadvantages. An example is in taxa where the branching order is uncertain and cannot be resolved, such as in the case of members of the genera Sulfitobacter, Staleya and Oceanibulbus (Labrenz et al., 2000; Wagner-Döbler et al., 2004). Arahal et al. (2005) have also noted a similar problem with 'unstable' dendrograms. In such cases, it is also impossible to define monophyletic groups based on these data alone. Where it is possible to define monophyletic groups, it is often forgotten that these are not necessarily genera and that the picture may change as more taxa are added. Given the fact that few more than 5000 prokaryotic species have yet been described and that estimates put the total number at anywhere between 50000 and 5 million, it is important to be aware that the majority of bacterial species remain to be described (Tindall, 2004). The Roseobacter clade is an excellent example of exactly this effect as more taxa have been added and have altered the 'monophyletic nature' of existing genera.

Although it is generally agreed that prokaryote taxonomy is probably best served by a polyphasic approach, the concept, as outlined by Wayne et al. (1987), gives priority to the $16 \mathrm{~S}$ rRNA gene sequence data in determining 'the phylogenetic position of a taxon'. That there may be problems with a taxonomy based primarily on 16S rRNA gene sequences is illustrated in members of the genus Hyphomonas (Badger et al., 2005; Lee et al., 2005). Cain \& Harrison (1960) clearly indicated that taxonomic systems based on single (or few parameters) are artificial (unless one can prove that one single gene represents the evolution of the whole organism) and that more broadly based systems give more 'natural' taxonomic systems [see Tindall (2002) for a discussion of the different meanings of 'natural']. It is also interesting to note that the principles followed here, as outlined by Tindall (1994) and put into practice by Labrenz et al. (1998, 1999, 2000, 2005), Biebl et al. (2005a, b) and Wagner-Döbler et al. (2004), are broadly in line with proposals made by Murray et al. (1990), a publication which is rarely followed or cited. A further consequence for this approach is the way that different datasets are interpreted and used in circumscribing taxa. Taxa that are difficult to distinguish by $16 \mathrm{~S}$ rRNA gene sequence or chemotaxonomic data such as Rsb. litoralis/Rsb. denitrificans or strain $\mathrm{T}^{\mathrm{T}} / R$ s b. gallaeciensis $\mathrm{BS} 107^{\mathrm{T}}$ can be distinguished by phenotypic (biochemical/physiological) data as well as by indirect comparisons (DNA-DNA hybridization) of their genomes. However, as chemical differences become evident and the 16S rRNA gene sequences diverge to a greater degree, phenotypic (biochemical/ physiological) differences may be more difficult to interpret and genome differences also increase. Interestingly, monophyletic groups ( $R s b$. litoralis/Rsb. denitrificans or strain $\mathrm{T}^{\mathrm{T}} / R s b$. gallaeciensis $\mathrm{BS}_{107^{\mathrm{T}}}$ ) are clearly evident when the chemical data are examined, indicating the significance of such data in helping to define and delineate evolutionary groups (Tindall, 1994). Combining $16 \mathrm{~S}$ rRNA gene sequence data, chemical data and phenotypic data in this way also has consequences for improving the taxon specificity of gene probes and detecting 'signature sequences' (B. J. Tindall, unpublished). Furthermore, taking such an approach to the circumscription of taxonomic groups also influences the way one evaluates the significance of taxonomy/nomenclature when genomes are compared.

Taken together, the data presented here indicate that Rsb. gallaeciensis $\mathrm{BS} 107^{\mathrm{T}}$ and strain $\mathrm{T}^{\mathrm{T}}$ represent two species in a novel genus. Further consequences of this work are that the description of the genus Roseobacter needs to be emended, as do the descriptions of the genera Leisingera and Ruegeria. The genus Roseobacter as originally defined by Shiba (1991) should be emended to take into account the chemotaxonomic data and also to exclude from this genus all species with the exception of Rsb. litoralis and Rsb. denitrificans. It is also proposed that the genus Leisingera as originally defined by Schaefer et al. (2002) should be emended to take into account the chemotaxonomic data and also to delineate this genus from all other genera that show a 16S rRNA gene sequence similarity of $>95 \%$. The genus Ruegeria as originally defined by Uchino et al. (1998) should be emended to take into account the chemotaxonomic data and to exclude from this genus all species with the exception of Ruegeria atlantica. A direct consequence of this work, emending the description of the genus Ruegeria as well as restricting that genus to one species, is that Ruegeria algicola (Lafay et al., 1995) Uchino et al., 1999 must be transferred to another genus. The new genus Marinovum is proposed to accommodate this species and the name Marinovum algicola comb. nov. is proposed for the type species. 
Given the fact that all of the emended or new descriptions involve the use of respiratory quinone, polar lipid and fatty acid data, we recommend, as did Murray et al. (1990), that future work on this group of Proteobacteria (and indeed others) includes all three datasets.

\section{Description of Phaeobacter gen. nov.}

Phaeobacter (Phae.o.bac'ter. Gr. adj. phaeos dark, brown; N.L. masc. n. bacter rod; N.L. masc. n. Phaeobacter a brown rod).

Cells are Gram-negative ovoid rods that multiply by binary fission. Tendency to aggregate in liquid MB 2216 medium. On marine agar 2216, colonies become brownish to dark brown and a diffusible brownish pigment is produced. The optimum salinity range is from 0.2 to $0.68 \mathrm{M} \mathrm{NaCl}$. The optimum $\mathrm{pH}$ is between $7 \cdot 0$ and $7 \cdot 5$. Cells are motile by means of polar flagella. Photosynthetic growth does not occur. Bchl $a$ is absent. Metabolism is chemoheterotrophic and obligately aerobic. Not able to reduce nitrate. No growth is observed with methyl iodide, methyl chloride or DMS. Oxidase- and catalase-positive, but negative for amylase, gelatinase and Tweenase. The major respiratory lipoquinone is Q10. The polar lipids comprise phosphatidylglycerol, phosphatidylethanolamine, phosphatidylcholine, an aminolipid and two unidentified lipids. The fatty acids comprise 3 -OH $10: 0,14: 1,3-\mathrm{OH} 12: 0,3-\mathrm{OH} 14: 1 / 3$-oxo $14: 0$, $16: 0,2-\mathrm{OH} 16: 0,18: 1 \omega 7 c, 18: 0$ and 11 -methyl $18: 1 \omega 7 c$. The 3-OH 10:0 and 2-OH 16:0 fatty acids were esterlinked, whereas the 3-OH $12: 0$ and $3-\mathrm{OH} 14: 1 / 3$-oxo $14: 0$ fatty acids were amide-linked. The type species is Phaeobacter gallaeciensis. The genus currently comprises two species, Phaeobacter gallaeciensis and Phaeobacter inhibens.

\section{Description of Phaeobacter gallaeciensis comb. nov.}

Phaeobacter gallaeciensis (gal.lae.ci.en'sis. L. masc. adj. gallaeciensis pertaining to Gallaecia the roman name for Galicia, the north-west region of Spain).

Basonym: Roseobacter gallaeciensis Ruiz-Ponte et al. 1998.

The description is the same as that for Roseobacter gallaeciensis (Ruiz-Ponte et al., 1998) with the following additions. Sensitive to penicillin G. Cells produce the antibiotic tropodithietic acid. Growth also occurs with butyrate and methionine as sole carbon sources. No growth of type strain with betaine.

The type strain is $B S 107^{\mathrm{T}}\left(=\mathrm{ATCC} \quad 700781^{\mathrm{T}}=\mathrm{CIP}\right.$ $105210^{\mathrm{T}}=$ NBRC $16654^{\mathrm{T}}=$ DSM $\left.17395^{\mathrm{T}}\right)$.

\section{Description of Phaeobacter inhibens sp. nov.}

Phaeobacter inhibens (in.hi'bens. L. part. adj. inhibens inhibiting).

Exhibits the following properties in addition to those given in the genus description. Cells are $1 \cdot 4-1 \cdot 9 \mu \mathrm{m} \times 0 \cdot 6-0 \cdot 8 \mu \mathrm{m}$.
Colonies on agar are smooth and convex with regular edges that become brownish/ochre on ferric-citrate-containing media after $24 \mathrm{~h}$ incubation at $20{ }^{\circ} \mathrm{C}$ and dark brown after incubation for $48 \mathrm{~h}$, with diameter up to $0.8 \mathrm{~mm}$. Tendency to aggregate in liquid MB 2216. Cells grow at temperatures ranging from 4 to $36^{\circ} \mathrm{C}$, with an optimum between 27 and $29^{\circ} \mathrm{C}$, and $\mathrm{pH}$ ranging from $6 \cdot 0$ to $9 \cdot 5$ (optimum $\mathrm{pH} 7 \cdot 5$ ). Cells grow in the presence of $\mathrm{Na}^{+}$concentrations of 0.01 and $<1.5 \mathrm{M}$, optimal salinity is between 0.51 and $0.68 \mathrm{M}$; no growth is observed without $\mathrm{Na}^{+}$. Oxidase- and catalasepositive, but amylase-, gelatinase- and Tweenase-negative. The following substrates are utilized: $(+)$-D-xylose, $(+)$-Dglucose, $(+)$-D-mannose, $(+)$-D-galactose, $(-)$-D-fructose, (-)-D-ribose, (-)-D-mannitol, (-)-D-sorbitol, (-)-D-glucosamine, sucrose, maltose, cellobiose, trehalose, sodium acetate, sodium pyruvate, sodium malate, sodium citrate, disodium succinate, sodium lactate, sodium propionate, sodium butyrate, xylan, glycerol, betaine, L-alanine, L-arginine, L-asparagine, L-aspartic acid, L-cysteine, L-glutamine, L-glutamic acid, L-glycine, L-histidine, L-isoleucine, L-leucine, L-lysine, L-methionine, L-phenylalanine, L-proline, L-serine, L-threonine, L-trytophan, L-tyrosine and L-valine. No growth is supported by the following substrates: $(+)$-Larabinose, $(+)$-L-rhamnose, $(-)$-L-fucose, lactose, sodium formate, starch, inulin, Tween 80, DMS, methyl iodide or methyl chloride. No vitamin requirements observed. Cells produce the antibiotic tropodithietic acid during the exponential growth phase and are susceptible to penicillin G, streptomycin sulphate and chloramphenicol. The DNA $\mathrm{G}+\mathrm{C}$ content is $55 \cdot 7 \mathrm{~mol} \%$.

The type strain, $\mathrm{T}^{\mathrm{T}}\left(=\mathrm{DSM} 16374^{\mathrm{T}}=\mathrm{LMG} 22475^{\mathrm{T}}\right)$, was isolated from surface water of a tidal mud flat in the German Wadden Sea, a southern region of the North Sea.

\section{Emended description of the genus Roseobacter Shiba 1991}

The description of the genus Roseobacter is as given by Shiba (1991), with the following additions. The major respiratory lipoquinone is Q10. The polar lipids are phosphatidylglycerol, two unidentified phospholipids and an aminolipid. The fatty acids comprise $3-\mathrm{OH} 10: 0,3-\mathrm{OH} 14: 1 / 3$-oxo $14: 0,16: 0,16: 1 \omega 7 c, 18: 1 \omega 7 c$ and $18: 0$. The $3-\mathrm{OH} 10: 0$ is ester-linked, while the 3 -OH $14: 1 / 3$-oxo $14: 0$ fatty acid is amide-linked. The type species of the genus is Roseobacter litoralis. The genus currently comprises two species, Roseobacter litoralis and Roseobacter denitrificans.

\section{Emended description of the genus Leisingera Schaefer et al. 2002}

Leisingera (Lei.sin'ge.ra. N.L. fem. n. Leisingera in honour of Thomas Leisinger, on the occasion of his retirement and for his contributions to our understanding of the biochemistry of bacterial methyl halide metabolism).

The description of the genus Leisingera is as given by Schaefer et al. (2002) with the following additions. The 
major respiratory lipoquinone present is Q10. The polar lipids comprise phosphatidylglycerol, phosphatidylethanolamine, an unidentified phospholipid, two unidentified lipids and an aminolipid. Phosphatidylcholine is not present. The fatty acids comprise $3-\mathrm{OH} 10: 0,14: 1,3-\mathrm{OH}$ $12: 0,16: 0,2-\mathrm{OH} 16: 0,18: 1 \omega 9 c, 18: 1 \omega 7 c, 18: 0$ and 11-methyl $18: 1 \omega 7 c$. The $3-\mathrm{OH} 10: 0$ and $2-\mathrm{OH} 16: 0$ fatty acids are ester-linked, while the $3-\mathrm{OH} 12: 0$ fatty acid is amide-linked. The type, and currently only, species of the genus is Leisingera methylohalidivorans.

\section{Emended description of the genus Ruegeria Uchino et al. 1999}

The description of the genus Ruegeria is as given by Uchino et al. (1998), with the following additions. The major respiratory lipoquinone present is Q10. The polar lipids comprise phosphatidylglycerol, phosphatidylethanolamine, phosphatidylcholine, two unidentified phospholipids and two unidentified lipids. The fatty acids comprise $3-\mathrm{OH}$ $10: 0,14: 0,3-\mathrm{OH} 12: 0,3-\mathrm{OH} 14: 1 / 3$-oxo- $14: 0,16: 0$,

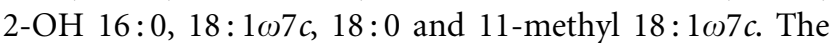
2-OH 16:0 fatty acid is ester-linked, the 3-OH 12:0 fatty acid appears to be both ester- and amide-linked, while the 3-OH 10:0 and 3-OH 14:1/3-oxo-14:0 are amide-linked. The type, and currently only, species of the genus is Ruegeria atlantica.

\section{Description of Marinovum gen. nov.}

Marinovum (Ma.ri.no'vum. L. adj. marinus of or belonging to the sea, marine; L. neut. n. ovum an egg, an egg-shape, oval; N.L. neut. n. Marinovum a marine egg-shaped bacterium).

Considering that this genus currently comprises only a single species, the description of the genus and type species is identical to that given by Lafay et al. (1995) for Roseobacter algicola, with additional chemotaxonomic data. The major respiratory lipoquinone present is Q10. The polar lipids comprise phosphatidylglycerol, phosphatidylethanolamine, phosphatidylcholine, an unidentified phospholipid, a single, unidentified lipid and an aminolipid. The fatty acids comprise $3-\mathrm{OH} 10: 0,3-\mathrm{OH} 12: 0,3-\mathrm{OH} 14: 1 / 3$-oxo-14:0, $18: 1 \omega 7 c, 18: 0$ and 11 -methyl $18: 1 \omega 7 c$. The $3-\mathrm{OH} 12: 0$ fatty acid appears to be both ester- and amide-linked, while the 3-OH 10:0 and 3-OH 14:1/3-oxo-14:0 fatty acid are amide-linked. The type, and currently, only species of the genus is Marinovum algicola.

\section{Description of Marinovum algicola comb. nov.}

Marinovum algicola (al.gi' co.la. L. n. alga alga; L. masc. suff. - cola from L. masc. n. incola an inhabitant; N.L. n. algicola alga dweller).

Basonym: Roseobacter algicola Lafay et al. 1995.

Other synonym: Ruegeria algicola Uchino et al. 1999.
The description of the species is as given for Roseobacter algicola by Lafay et al. (1995). The type strain is $\mathrm{FF}^{\mathrm{T}}$ $\left(=\right.$ ATCC $51440^{\mathrm{T}}=$ CIP $\quad 104267^{\mathrm{T}}=\mathrm{DSM} \quad 10251^{\mathrm{T}}=\mathrm{IAM}$ $14591^{\mathrm{T}}=$ NBRC $16653^{\mathrm{T}}$ ).

\section{ACKNOWLEDGEMENTS}

We thank Erko Stackebrandt for helpful discussions, Hans G. Trüper for help with the epithet, Jean Euzéby for proposing the genus name Marinovum and Renate Gahl-Janssen for technical assistance. This work was supported by grants from the Volkswagen Foundation within the Lower Saxony priority program Marine Biotechnology.

\section{REFERENCES}

Arahal, D. R., Macián, M. C., Garay, E. \& Pujalte, M. J. (2005). Thalassobius mediterraneus gen. nov., sp. nov., and reclassification of Ruegeria gelatinovorans as Thalassobius gelatinovorus comb. nov. Int J Syst Evol Microbiol 55, 2371-2376.

Badger, J. H., Eisen, J. A. \& Ward, N. L. (2005). Genomic analysis of Hyphomonas neptunium contradicts 16S rRNA gene-based phylogenetic analysis: implications for the taxonomy of the orders 'Rhodobacterales' and Caulobacterales. Int J Syst Evol Microbiol 55, 1021-1026.

Biebl, H., Allgaier, M., Tindall, B. J., Koblizek, M., Lünsdorf, H., Pukall, R. \& Wagner-Döbler, I. (2005a). Dinoroseobacter shibae gen. nov., sp. nov., a new aerobic phototrophic bacterium isolated from dinoflagellates. Int J Syst Evol Microbiol 55, 1089-1096.

Biebl, H., Allgaier, M., Lünsdorf, H., Pukall, R., Tindall, B. J. \& Wagner-Döbler, I. (2005b). Roseovarius mucosus sp. nov., a member of the Roseobacter clade with trace amounts of bacteriochlorophyll $a$. Int J Syst Evol Microbiol 55, 2377-2383.

Brinkhoff, T. \& Muyzer, G. (1997). Increased species diversity and extended habitat range of sulfur-oxidizing Thiomicrospira spp. Appl Environ Microbiol 63, 3789-3796.

Brinkhoff, T., Bach, G., Heidorn, T., Liang, L., Schlingloff, A. \& Simon, M. (2004). Antibiotic production by a Roseobacter cladeaffiliated species from the German Wadden Sea and its antagonistic effects on indigenous isolates. Appl Environ Microbiol 70, 2560-2565.

Cain, A. J. \& Harrison, G. A. (1960). Phyletic weighting. Proc Zool Soc Lond 131, 1-31.

Cashion, P., Holder-Franklin, M. A., McCully, J. \& Franklin, M. (1977). A rapid method for the base ratio determination of bacterial DNA. Anal Biochem 81, 461-466.

Chavez, F. P., Lünsdorf, H. \& Jerez, C. A. (2004). Growth of polychlorinated-biphenyl-degrading bacteria in the presence of biphenyl and chlorobiphenyls generates oxidative stress and massive accumulation of inorganic polyphosphate. Appl Environ Microbiol 70, 3064-3072.

De Ley, J. (1967). Molecular biology and bacterial phylogeny. In Evolutionary Biology, vol. 2, pp. 103-156. Edited by T. Dobzhansky, M. K. Hecht \& W. C. Steere. New York: Plenum.

De Ley, J., Cattoir, H. \& Reynaerts, A. (1970). The quantitative measurement of DNA hybridization from renaturation rates. Eur $J$ Biochem 12, 133-142.

Escara, J. F. \& Hutton, J. R. (1980). Thermal stability and renaturation of DNA in dimethyl sulfoxide solutions: acceleration of the renaturation rate. Biopolymers 19, 1315-1327. 
Giovannoni, S. \& Rappé, M. (2000). Evolution, diversity and molecular ecology of marine prokaryotes. In Microbial Ecology of the Ocean, pp. 47-84. Edited by D. L. Kirchman. New York: Wiley.

Gram, L., Grossart, H. P., Schlingloff, A. \& Kiorboe, T. (2002). Possible quorum sensing in marine snow bacteria: production of acylated homoserine lactones by Roseobacter strains isolated from marine snow. Appl Environ Microbiol 68, 4111-4116.

Gregersen, T. (1978). Rapid method for distinction of gram-negative from gram-positive bacteria. Eur J Appl Microbiol 5, 123-127.

Huß, V. A. R., Festl, H. \& Schleifer, K. H. (1983). Studies on the spectrophotometric determination of DNA hybridization from renaturation rates. Syst Appl Microbiol 4, 184-192.

Jahnke, K. D. (1992). BASIC computer program for evaluation of spectroscopic DNA renaturation data from GILFORD System 2600 spectrophotometer on a $\mathrm{PC} / \mathrm{XT} / \mathrm{AT}$ type personal computer. J Microbiol Methods 15, 61-73.

Labrenz, M., Collins, M. D., Lawson, P. A., Tindall, B. J., Braker, G. \& Hirsch, P. (1998). Antarctobacter heliothermus gen. nov., sp. nov., a budding bacterium from hypersaline and heliothermal Ekho Lake. Int J Syst Bacteriol 48, 1363-1372.

Labrenz, M., Collins, M. D., Lawson, P. A., Tindall, B. J., Schumann, P. \& Hirsch, P. (1999). Roseovarius tolerans gen. nov., sp. nov., a budding bacterium with variable bacteriochlorophyll $a$ production from hypersaline Ekho Lake. Int J Syst Bacteriol 49, 137-147.

Labrenz, M., Tindall, B. J., Lawson, P. A., Collins, M. D., Schumann, P. \& Hirsch, P. (2000). Staleya guttiformis gen. nov., sp. nov. and Sulfitobacter brevis sp. nov., $\alpha$-3-Proteobacteria from hypersaline, heliothermal and meromictic antarctic Ekho Lake. Int J Syst Evol Microbiol 50, 303-313.

Labrenz, M., Lawson, P. A., Tindall, B. J., Collins, M. D. \& Hirsch, P. (2005). Roseisalinus antarcticus gen. nov., sp. nov., a novel aerobic bacteriochlorophyll $a$-producing $\alpha$-proteobacterium isolated from hypersaline Ekho Lake, Antarctica. Int J Syst Evol Microbiol 55, 41-47.

Lafay, B., Ruimy, R., de Traubenberg, C. R., Breittmayer, V., Gauthier, M. J. \& Christen, R. (1995). Roseobacter algicola sp. nov., a new marine bacterium isolated from the phycosphere of the toxin-producing dinoflagellate Prorocentrum lima. Int J Syst Bacteriol 45, 290-296.

Lee, K.-B., Liu, C.-T., Anzai, Y., Kim, H., Aono, T. \& Oyaizu, H. (2005). The hierarchical system of the 'Alphaproteobacteria': description of Hyphomonadaceae fam. nov., Xanthobacteraceae fam. nov. and Erythrobacteraceae fam. nov. Int J Syst Evol Microbiol 55, 1907-1919.

Ludwig, W., Strunk, O., Westram, R. \& 29 other authors (2004). ARB: a software environment for sequence data. Nucleic Acids Res 32, 1363-1371.

Mesbah, M., Premachandran, U. \& Whitman, W. B. (1989). Precise measurement of the $\mathrm{G}+\mathrm{C}$ content of deoxyribonucleic acid by highperformance liquid chromatography. Int J Syst Bacteriol 39, 159-167.

Murray, R. G. E., Brenner, D. J., Colwell, R. R., De Vos, P., Goodfellow, M., Grimont, P. A. D., Pfennig, N., Stackebrandt, E. \& Zavarzin, G. A. (1990). Report of the ad hoc committee on approaches to taxonomy within the Proteobacteria. Int J Syst Bacteriol 40, 213-215.

Neumann, U., Mayer, H., Schiltz, E., Benz, R. \& Weckesser, J. (1995). Lipopolysaccharide and porin of Roseobacter denitrificans, confirming its phylogenetic relationship to the $\alpha-3$ subgroup of the Proteobacteria. Microbiology 141, 2013-2017.

Rathgeber, C., Beatty, J. T. \& Yurkov, V. (2004). Aerobic phototrophic bacteria: new evidence for the diversity, ecological importance and applied potential of this previously overlooked group. Photosynth Res 81, 113-128.

Ruiz-Ponte, C., Cilia, V., Lambert, C. \& Nicolas, J. L. (1998). Roseobacter gallaeciensis sp. nov., a new marine bacterium isolated from rearings and collectors of the scallop Pecten maximus. Int J Syst Bacteriol 48, 537-542.

Ruiz-Ponte, C., Samain, J. F., Sanchez, J. L. \& Nicolas, J. L. (1999). The benefit of a Roseobacter species on the survival of scallop larvae. Mar Biotechnol 1, 52-59.

Ryu, E. (1937). A simple method of staining bacterial flagella. Kitasatoo Arch Exp Med 14, 218-219.

Schaefer, J. K., Goodwin, K. D., McDonald, I. R., Murrell, J. C. \& Oremland, R. S. (2002). Leisingera methylohalidivorans gen. nov., sp. nov., a marine methylotroph that grows on methyl bromide. Int J Syst Evol Microbiol 52, 851-859.

Shiba, T. (1991). Roseobacter litoralis gen. nov., sp. nov., and Roseobacter denitrificans sp. nov., aerobic pink-pigmented bacteria which contain bacteriochlorophyll a. Syst Appl Microbiol 14, 140-145.

Smibert, R. M. \& Krieg, N. R. (1994). Phenotypic characterization. In Methods for General and Molecular Bacteriology, pp. 607-654. Edited by P. Gerhardt, R. G. E. Murray, W. A. Wood \& N. R. Krieg. Washington, DC: American Society for Microbiology.

Stackebrandt, E. \& Liesack, W. (1993). Nucleic acids and classification. In Handbook of New Bacterial Systematics, pp. 158-160. Edited by M. Goodfellow \& A. G. O’Donnell. London: Academic Press.

Strömpl, C., Tindall, B. J., Jarvis, G. N., Lünsdorf, H., Moore, E. R. B. \& Hippe, H. (1999). A re-evaluation of the taxonomy of the genus Anaerovibrio, with the reclassification of Anaerovibrio glycerini as Anaerosinus glycerini gen. nov., comb. nov., and Anaerovibrio burkinabensis as Anaeroarcus burkinensis [corrig.] gen. nov., comb. nov. Int J Syst Bacteriol 49, 1861-1872.

Tamaoka, J. \& Komagata, K. (1984). Determination of DNA base composition by reversed-phase high-performance liquid chromatography. FEMS Microbiol Lett 25, 125-128.

Tindall, B. J. (1990a). A comparative study of the lipid composition of Halobacterium saccharovorum from various sources. Syst Appl Microbiol 13, 128-130.

Tindall, B. J. (1990b). Lipid composition of Halobacterium lacusprofundi. FEMS Microbiol Lett 66, 199-202.

Tindall, B. J. (1994). Chemical analysis of Archaea and Bacteria: a critical evaluation of its use in taxonomy and identification. In Bacterial Diversity and Systematics (FEMS Symposium no. 75), pp. 243-258. Edited by F. G. Priest, A. Ramos-Cormenzana \& B. J. Tindall. New York: Plenum.

Tindall, B. J. (1996). Respiratory lipoquinones as biomarkers. In Molecular Microbial Ecology Manual, section 4.1.5, supplement 1. Edited by A. Akkermans, F. de Bruijn \& D. van Elsas. Dordrecht: Kluwer.

Tindall, B. J. (2002). Prokaryotic systematics: a theoretical overview. Encyclopedia of Life Sciences. London: Wiley. http://els.wiley.com

Tindall, B. J. (2004). Prokaryotic diversity in the Antarctic: the tip of the Iceberg. Microb Ecol 47, 271-283.

Tschech, A. \& Pfennig, N. (1984). Growth yield increase linked to caffeate reduction in Acetobacterium woodii. Arch Microbiol 137, 163-167.

Uchino, Y., Hirata, A., Yokota, A. \& Sugiyama, J. (1998). Reclassification of marine Agrobacterium species: proposals of Stappia stellulata gen. nov., comb. nov., Stappia aggregata sp. nov., nom. rev., Ruegeria atlantica gen. nov., comb. nov., Ruegeria gelatinovora comb. nov., Ruegeria algicola comb. nov., and Ahrensia kieliense gen. nov., sp. nov., nom. rev. J Gen Appl Microbiol 44, 201-210.

Uchino, Y., Hirata, A., Yokota, A. \& Sugiyama, J. (1999). Ruegeria algicola (basonym Roseobacter algicola) comb. nov. In Validation of the Publication of New Names and New Combinations Previously Effectively Published Outside the IJSB, List no. 68. Int J Svst Bacteriol 49, 1-3.

Wagner-Döbler, I., Rheims, H., Felske, A., El-Ghezal, A., Flade-Schröder, D., Laatsch, H., Lang, S., Pukall, R. \& Tindall, B. J. (2004). Oceanibulbus 
indolifex gen. nov., sp. nov., a North Sea alphaproteobacterium that produces bioactive metabolites. Int J Syst Evol Microbiol 54, 1177-1184.

Wayne, L. G., Brenner, D. J., Colwell, R. R. \& 9 other authors (1987). International Committee on Systematic Bacteriology. Report of the ad hoc committee on reconciliation of approaches to bacterial systematics. Int J Syst Bacteriol 37, 463-464.

Yurkov, V. V. \& Beatty, J. T. (1998). Aerobic anoxygenic phototrophic bacteria. Microbiol Mol Biol Rev 62, 695-724. 